\title{
Culturable epibacteria of the marine sponge Ircinia fusca: temporal variations and their possible role in the epibacterial defense of the host
}

\author{
Narsinh L. Thakur ${ }^{1,2}$, Arga C. Anil ${ }^{1, *}$, Werner E. G. Müller ${ }^{2}$ \\ ${ }^{1}$ Marine Corrosion \& Materials Research Division, National Institute of Oceanography, Dona Paula, 403004 Goa, India \\ ${ }^{2}$ Institut für Physiologische Chemie, Abteilung Angewandte Molekularbiologie, Universität Mainz, Duesbergweg 6, \\ 55099 Mainz, Germany
}

\begin{abstract}
The influence of environmental changes on the epibacterial population of the marine sponge Ircinia fusca (Carter) was evaluated by using a bacterial culture-based approach. Sponge surface-associated bacteria were isolated, enumerated and cultured during 5 different collection periods. These bacteria were assessed for antibacterial activity against fouling bacteria and for autoinhibition with their extracts, using the ecologically relevant agar plug method. Morphological studies of all culturable sponge-associated bacteria were carried out and the isolates with antibacterial potential were further identified using 16S rRNA gene sequences. It was found that the epibacterial population of the sponge is influenced by temporal changes in the environment. However, the bacterial strain belonging to the genus Bacillus, which displayed antibacterial activity against fouling bacteria, was found to be associated with the sponge in every collection period, indicating close association of this strain with the sponge I. fusca. The sponge seems to have selective control of the bacterial epibiosis on its surface. The antibacterial assay of sponge extract against its associated bacteria showed that the sponge promotes the growth of certain antibiotic producing strains of the genus Bacillus, which may indirectly help the sponge in governing epibacterial populations on its surface by deterring settlement of other microbes from the vicinity. In summary, this investigation explores the possible role of sponge surface-associated bacteria in the epibacterial defense of the host, by considering the temporal variations in the habitat.
\end{abstract}

KEY WORDS: Sponge $\cdot$ Bacteria $\cdot$ Epibacterial defense $\cdot$ Temporal variation $\cdot$ Antibacterial activity

\section{INTRODUCTION}

The bacterial association with marine sponges has been well known for a long time (Vacelet 1975) and several investigations have explored this association using different approaches. It has been reported that in some sponge species as much as $40 \%$ of animal biomass is attributed to bacteria, which exceeds the bacterial population of seawater by 2 orders of magnitude (Friedrich et al. 2001). In recent years, marine sponges have been considered to be a rich reserve of compounds, possessing novel structures and exhibiting interesting biological activities (reviewed in Faulkner
1997, Schröder et al. 2003). However, as sponges harbor diverse bacterial populations, it is under scientific debate whether the sponge and/or its associated bacteria produce these bioactive molecules reported to come from the sponge. The ecological implications of the sponge-bacteria association have been enhanced by the significance of marine sponges in drug research.

In order to address the biochemical interaction and basis of bacterial symbiosis in marine sponges, most of the studies were carried out with bacteria which reside within sponges (Vacelet \& Donadey 1977, Wilkinson 1978a,b,c, Santavy et al. 1990, Althoff et al. 1998, Friedrich et al. 1999, 2001, Webster \& Hill 2001, Web- 
ster et al. 2001, Thacker \& Starnes 2003). As sponges are constantly exposed to a large number of bacteria that colonize their surfaces, the study of the association between sponges and their surface-associated bacteria is of equal importance. In addition, to investigate the role of associated bacteria in the epibacterial defense of the host, one should ideally focus on the host's surface bacterial population.

In the marine environment, any substratum (including living organisms) is rapidly colonized by microorganisms (epibiosis), which further leads to the settlement of macroorganisms. Epibiosis is a very important process for marine organisms, as it causes a variety of beneficial and adverse effects (Wahl 1989). As bacteria play a major role in microfilm formation, it becomes vital, especially for soft-bodied organisms like sponges, to regulate bacterial epibiosis on their surfaces. It is known that the physical and chemical characteristics of a basibiont's surface influence the colonization of epibionts in the marine environment (Patil \& Anil 2000). The bacterial colonization of marine organisms is also reported to be governed by secondary metabolites produced by the host (McCaffrey \& Endean 1985, Amade et al. 1987, Becerro et al. 1994, Wahl et al. 1994, Slattery et al. 1995, Steinberg et al. 1997, Newbold et al. 1999, Kelman et al. 2001). In addition, some recent studies, including those on sponges, have indicated that epibiotic bacteria also play an important role in the epibacterial defense of the host (Holmström et al. 1996, Boyd et al. 1999, Holmström \& Kjelleberg 1999, Thakur \& Anil 2000). While reporting the antifouling activity of marine surface-associated Pseudoalteromonas sp., Holmström et al. (2002) concluded that some bacteria may aid its host in preventing colonization on its surface. Harder et al. (2003) also highlights the importance of bacteria in the epibacterial defense of the soft coral Dendronephthya sp. In our studies on Suberites domuncula, we suggested that the sponge may be provided with a direct (by producing antibacterial metabolites) and indirect (with the help of associated bacteria) epibacterial defense (Thakur et al. 2003).

The variability in bacterial epibiosis can be attributed to the surface characteristics of the host organism, but one cannot neglect the influence of environmental changes in the temperature of the water column. It was noted that the intensity of bacterial epibiosis on a sponge surface varies with such changes in the environment (Thakur 2001). This highlights the significance of temporal evaluation of sponge surface-associated bacteria and their role in the epibacterial defense of the host. The stability of bacterial communities associated with sponges has not been studied widely and has ecological and biotechnological implications as well.
Considering these observations, the present investigation aims to explore the importance of sponge surface-associated bacteria in the epibacterial defense of the host, with special emphasis on temporal variations in the epibacterial population. This study was carried out with the marine sponge Ircinia fusca (Carter), which belongs to the class Demospongiae. This species grows like a wall (lamellar growth form) in the intertidal rocky habitats and, despite severe competition for space by fouling organisms, it remains free from macro-epibionts.

\section{MATERIALS AND METHODS}

Sponge collection. Specimens of the marine sponge Ircinia fusca were collected from intertidal rock pools at Ratnagiri, along the central west coast of India $\left(16^{\circ}\right.$ 59.5' N, 73 16.5' E) during May 1997, January 1998, May 1998, October 1998 and January 1999. During every collection, 3 sponge specimens were taken along with surrounding seawater, placed separately in glass beakers and brought to the field laboratory within $1 \mathrm{~h}$.

Isolation, enumeration, culture and identification of sponge surface-associated bacteria (SAB). Once in the laboratory, the specimens were placed separately in beakers with sterile seawater, which was changed 4 to 5 times in order to remove free bacteria in water and on the sponge surface. A small area of each specimen $\left(1 \mathrm{~cm}^{2}\right)$ was softly swabbed with a sterile cotton tip applicator, by placing a sterile plastic film with a $1 \mathrm{~cm}^{2}$ hole on the specimen surface. The applicator tip was placed in a tube containing $10 \mathrm{ml}$ of sterile seawater (Wahl et al. 1994). After vigorous mixing and serial dilutions (1:5), $3 \times 100 \mu$ of each dilution were plated on Zobell marine agar plates (Himedia Laboratories, Product No. M384). Bacterial colonies on the plates were counted after 24 to $72 \mathrm{~h}$ incubation at $30^{\circ} \mathrm{C}$. The density of bacteria is expressed in terms of number of colony forming units (CFU) $\mathrm{cm}^{-2}$ for each specimen. Variation in epibacterial density over the sponge surface during different collection periods (log-transformed values) was subjected to 1-way ANOVA with equal sample size (Sokal \& Rohlf 1981). After isolation, SAB were purified and cultured on Zobell marine agar slants. These bacteria were identified to the family and/or genus, using different biochemical tests such as the Methyl Red test, the Voges-Proskauer test, the Indole test, the citrate test, triple sugar iron agar, nitrate reduction, urea hydrolysis, catalase production, oxidase production, gelatinase, coagulase, carbohydrate fermentation, starch hydrolysis etc. (Buchanan \& Gibbons 1984). 
Isolation, enumeration and culture of vicinity fouling bacteria (VFB). Fouling bacteria were isolated and enumerated from microfilm developed over aluminum, fiberglass and cupronickel panels $(10 \times 15 \mathrm{~cm})$ exposed for $48 \mathrm{~h}$ in the immediate vicinity of sponge, following the procedure described above (see isolation of SAB method). Bacterial colonies on the plates were counted after 24 to $72 \mathrm{~h}$ incubation at $30^{\circ} \mathrm{C}$. The density of bacteria is expressed in terms of number of CFU $\mathrm{cm}^{-2}$ for every type of panel. Variation in the VFB density in the water column during different collections (log-transformed values) was subjected to 2-way ANOVA without replicates (factors: panels and seasons) (Sokal \& Rohlf 1981). After isolation, bacterial colonies were separated according to their color and morphology and cultured in pure strains on Zobell marine agar slants. As these fouling bacteria were used only as test strains for antibacterial assays, they were not further identified.

Preparation of organic extracts. After collection, sponge specimens were rinsed with seawater, pooled and placed in methanol (Qualigens, AR grade) and brought to the laboratory. After $2 \mathrm{~d}$, the extract was decanted and collected. The extraction was repeated 3 times, using the same quantity of fresh methanol. These extracts were pooled, filtered and concentrated under reduced pressure using a rotary evaporator. The crude methanol extract was stored below $5^{\circ} \mathrm{C}$ and further used for antibacterial activity.

The SAB obtained from all the collection periods were extracted in n-butanol, following a method of Elyakov et al. (1996). Bacterial isolates were inoculated into conical flasks (1 l capacity) with $500 \mathrm{ml}$ cultural broth (peptone, $5.0 \mathrm{~g} ; \mathrm{K}_{2} \mathrm{HPO}_{4}, 0.2 \mathrm{~g}$; yeast extract, $2.5 \mathrm{~g}$; glucose, $1.0 \mathrm{~g} ; \mathrm{MgSO}_{4}, 0.2 \mathrm{~g}$; seawater, $500 \mathrm{ml}$; distilled water, $500 \mathrm{ml}$; sterilization at $121^{\circ} \mathrm{C}$ for $20 \mathrm{~min}$, $\mathrm{pH} 7.2$ to 7.5$)$. The flasks were incubated at $30^{\circ} \mathrm{C}$ for $3 \mathrm{~d}$ with shaking (100 rpm). After addition of $150 \mathrm{ml}$ of n-butanol, the mixtures were kept at $40^{\circ} \mathrm{C}$ for $24 \mathrm{~h}$, stirred for $20 \mathrm{~min}$, centrifuged and the butanol layer was evaporated using a rotary evaporator. Dry residues were stored below $5^{\circ} \mathrm{C}$ until further use.

Antibacterial assays. Sponge extract was assayed against $\mathrm{SAB}$, using the disc diffusion method as described earlier (Thakur \& Anil 2000). Antibacterial activity of SAB collected during different periods was tested in triplicate against all VFB isolated in that particular collection month and common fouling bacteria (CFB, obtained from other locations), using the well diffusion method (Elyakov et al. 1996) and agar plug method (Hentschel et al. 2001). Antibacterial activity of $\mathrm{SAB}$ was also tested against $\mathrm{SAB}$ isolated in that particular collection month, using both methods.

In the well diffusion method, wells of $1 \mathrm{~cm}$ diameter were made on agar plates and these plates were swabbed with test bacterial isolates. The wells in the agar plates were subsequently filled with $100 \mu \mathrm{LAB}$ extract $\left(500 \mu \mathrm{g}\right.$ well $\left.^{-1}\right)$, previously dissolved in sterile distilled water. Controls were run by putting sterile distilled water into the wells and they were observed not to inhibit bacterial growth. The diameter of the inhibition zone surrounding each well was measured after $24 \mathrm{~h}$ incubation at $30^{\circ} \mathrm{C}$. Results are presented in the form of diameter of inhibition zone (total diameter of inhibition zone-diameter of well) and percentage inhibition of test bacterial isolates (number of bacteria inhibited/total number of bacteria tested in the assay 100).

In the agar plug method, the SAB cultures $(150 \mu \mathrm{l})$ were grown overnight as a lawn on Zobell marine agar. Plugs of $10 \mathrm{~mm}$ diameter were stanced out with a cork-borer and placed with the bacterial side down on agar plates, which had been seeded with a stationary phase culture of the test bacterial strain. Agar plugs without bacteria were used as controls and were observed not to inhibit bacterial growth. The diameter of the inhibition zone surrounding the agar plugs was measured after $24 \mathrm{~h}$ incubation at $30^{\circ} \mathrm{C}$. Results are presented in the form of diameter of inhibition zone (total diameter of inhibition zone - diameter of plug) and percentage inhibition of test bacterial isolates (number of bacteria inhibited/total number of bacteria tested in the assay $\times 100$ ).

Phylogenetic identification of SAB. Out of $5 \mathrm{SAB}$ isolates with antibacterial activity (Table 1), JSP2.98 and MSP2.98 could not grow on agar plates after repeated sub culture. Hence, identification of the remaining $3 \mathrm{SAB}$ isolates (MSP2.97, OSP5.98 and JSP2.99) was carried out by using 16S rRNA gene sequences (Hentschel et al. 2001).

DNA was extracted from 3 stationary phase cultures using the standard phenol-chloroform extraction procedure. PCR amplification was performed in a total volume of $50 \mu \mathrm{l}$ containing the appropriate reaction buffer and reagents, $4 \mathrm{U}$ of DAP polymerase (Goldstar, Eurogentec) and the universal primers $27 \mathrm{f}$ (5'-GAGTTTGATCCTGGCTCA-3') and 1385r (5'CGGTGTGT(A/G)CAAGGCCC-3'), corresponding to Escherichia coli 16S rDNA numbering. The conditions were as follows: initial denaturation $\left(2 \mathrm{~min}\right.$ at $\left.95^{\circ} \mathrm{C}\right)$, followed by 30 cycles of denaturation $\left(1 \mathrm{~min}\right.$ at $\left.95^{\circ} \mathrm{C}\right)$, primer annealing $\left(1 \mathrm{~min}\right.$ at 50 to $54^{\circ} \mathrm{C}$ adjusted for individual strains) and primer extension (1.5 min at $72^{\circ} \mathrm{C}$ ).

The PCR amplification product was purified using the geneclean kit (Bio 101). The recovered fragment was sequenced on a Li-Cor 4200 automated sequencer using sequencing primers. The obtained sequences were aligned using ABI prism Auto assembler v. 2.1 software (Perkin Elmer) and entered into the BLAST and $\mathrm{ARb}$ 16S rDNA sequence database (see www.arbhome.de). 
Table 1. Morphological characteristics of sponge surface-associated bacteria (SAB). These bacteria were identified to the family and/or genus with the help of different biochemical tests, by using Bergey's manual of determinative bacteriology (Buchanan \& Gibbons 1984). (Bacterial isolates in bold exhibited antibacterial activity against fouling bacteria)

\begin{tabular}{|c|c|c|c|c|c|c|}
\hline Date & Isolate & $\begin{array}{c}\text { Cell } \\
\text { morphology }\end{array}$ & Color & Motility & $\begin{array}{l}\text { Gram } \\
\text { staining }\end{array}$ & Family/genus \\
\hline May 1997 & $\begin{array}{l}\text { MSP1.97 } \\
\text { MSP2.97 } \\
\text { MSP3.97 }\end{array}$ & $\begin{array}{l}\text { Rods } \\
\text { Rods } \\
\text { Rods }\end{array}$ & $\begin{array}{l}\text { Peach } \\
\text { Cream } \\
\text { Cream }\end{array}$ & $\begin{array}{l}\text { Motile } \\
\text { Motile } \\
\text { Motile }\end{array}$ & $\begin{array}{l}- \\
+ \\
-\end{array}$ & $\begin{array}{l}\text { Pseudomonas sp. } \\
\text { Bacillus sp. } \\
\text { Pseudomonas sp. }\end{array}$ \\
\hline January 1998 & $\begin{array}{l}\text { JSP1.98 } \\
\text { JSP2.98 } \\
\text { JSP3.98 } \\
\text { JSP4.98 } \\
\text { JSP5.98 } \\
\text { JSP6.98 }\end{array}$ & $\begin{array}{l}\text { Rods } \\
\text { Cocci } \\
\text { Rods } \\
\text { Cocci } \\
\text { Cocci } \\
\text { Rods }\end{array}$ & $\begin{array}{l}\text { Orange } \\
\text { Cream } \\
\text { Cream } \\
\text { Yellow } \\
\text { Orange } \\
\text { Yellow }\end{array}$ & $\begin{array}{l}\text { Motile } \\
\text { Non-motile } \\
\text { Motile } \\
\text { Non-motile } \\
\text { Non-motile } \\
\text { Non-motile }\end{array}$ & $\begin{array}{l}- \\
+ \\
- \\
+ \\
+ \\
-\end{array}$ & $\begin{array}{l}\text { Enterobacteriaceae } \\
\text { Micrococcus sp. } \\
\text { Vibrio sp. } \\
\text { Staphylococcus sp. } \\
\text { Staphylococcus sp. } \\
\text { Flavobacterium sp. }\end{array}$ \\
\hline May 1998 & $\begin{array}{l}\text { MSP1.98 } \\
\text { MSP2.98 } \\
\text { MSP3.98 } \\
\text { MSP4.98 } \\
\text { MSP5.98 }\end{array}$ & $\begin{array}{l}\text { Cocci } \\
\text { Rods } \\
\text { Rods } \\
\text { Cocci } \\
\text { Rods }\end{array}$ & $\begin{array}{l}\text { Cream } \\
\text { Cream } \\
\text { Cream } \\
\text { Cream } \\
\text { Orange }\end{array}$ & $\begin{array}{l}\text { Non-motile } \\
\text { Motile } \\
\text { Motile } \\
\text { Non-motile } \\
\text { Motile }\end{array}$ & $\begin{array}{l}+ \\
+ \\
- \\
+ \\
-\end{array}$ & $\begin{array}{l}\text { Micrococcus sp. } \\
\text { Bacillus sp. } \\
\text { Pseudomonas sp. } \\
\text { Micrococcus sp. } \\
\text { Enterobacteriaceae }\end{array}$ \\
\hline October 1998 & $\begin{array}{l}\text { OSP1.98 } \\
\text { OSP2.98 } \\
\text { OSP3.98 } \\
\text { OSP4.98 } \\
\text { OSP5.98 }\end{array}$ & $\begin{array}{l}\text { Cocci } \\
\text { Cocci } \\
\text { Cocci } \\
\text { Rods } \\
\text { Rods }\end{array}$ & $\begin{array}{l}\text { Cream } \\
\text { Cream } \\
\text { Yellow } \\
\text { Cream } \\
\text { Cream }\end{array}$ & $\begin{array}{l}\text { Non-motile } \\
\text { Non-motile } \\
\text { Non-motile } \\
\text { Motile } \\
\text { Motile }\end{array}$ & $\begin{array}{l}+ \\
+ \\
+ \\
- \\
+\end{array}$ & $\begin{array}{l}\text { Micrococcus sp. } \\
\text { Micrococcus sp. } \\
\text { Staphylococcus sp. } \\
\text { Vibrio sp. } \\
\text { Bacillus sp. }\end{array}$ \\
\hline January 1999 & $\begin{array}{l}\text { JSP1.99 } \\
\text { JSP2.99 } \\
\text { JSP3.99 } \\
\text { JSP4.99 } \\
\text { JSP5.99 } \\
\text { JSP6.99 }\end{array}$ & $\begin{array}{l}\text { Cocci } \\
\text { Rods } \\
\text { Rods } \\
\text { Cocci } \\
\text { Rods } \\
\text { Rods }\end{array}$ & $\begin{array}{l}\text { Cream } \\
\text { Cream } \\
\text { Cream } \\
\text { Cream } \\
\text { Orange } \\
\text { Cream }\end{array}$ & $\begin{array}{l}\text { Non-motile } \\
\text { Motile } \\
\text { Motile } \\
\text { Non-motile } \\
\text { Motile } \\
\text { Motile }\end{array}$ & $\begin{array}{l}+ \\
+ \\
- \\
+ \\
- \\
+\end{array}$ & $\begin{array}{l}\text { Micrococcus sp. } \\
\text { Bacillus sp. } \\
\text { Pseudomonas sp. } \\
\text { Micrococcus sp. } \\
\text { Enterobacteriaceae } \\
\text { Bacillus sp. }\end{array}$ \\
\hline
\end{tabular}

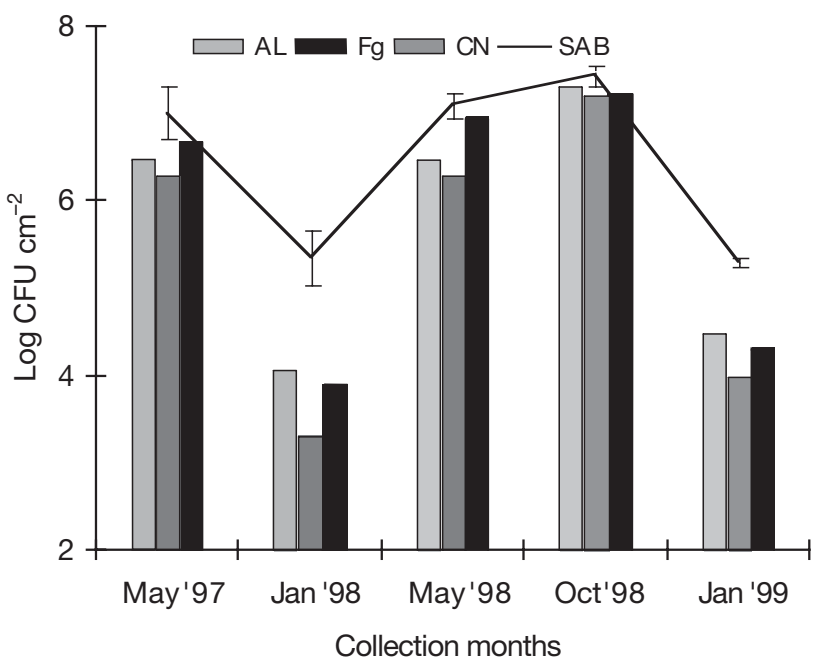

Fig. 1. Density of sponge vicinity fouling bacteria (VFB) and sponge surface-associated bacteria (SAB) in different collection periods. Vertical bars on SAB density line indicate $\pm \mathrm{SD}$. Toxic (CN: cupronickel) and non-toxic surfaces (AL: aluminum and Fg: fiberglass) were immersed in the vicinity of the sponge to collect fouling bacteria. CFU: colony forming unit

\section{RESULTS}

\section{Sponge surface-associated bacteria (SAB)}

A quantitative temporal variation in the epibacterial density was observed. In May 1997, May 1998 and October 1998, sponge surfaces had dense bacterial populations compared to January 1998 and January 1999 (Fig. 1; CFU cm ${ }^{-2}$ is given in the form of log-transformed values). The application of 1-way ANOVA showed the temporal variation in the epibacterial density to be significant (details of the ANOVA analysis: $\left.\mathrm{df}=4, \mathrm{SS}=116.40, \mathrm{MS}=29.10, F_{\mathrm{S}}=4.45, \mathrm{p} \leq 0.001\right)$.

Morphological characteristics of all these culturable $\mathrm{SAB}$ isolates are given in Table 1. Three bacterial isolates were obtained during May 1997 (MSP1.97 to MSP3.97), 6 isolates (JSP1.98 to JSP6.98) during January 1998, 5 isolates (MSP1.98 to MSP5.98) during May 1998, 5 isolates (OSP1.98 to OSP5.98) during October 1998 and 6 isolates (JSP1.99 to JSP6.99) during January 1999. In total, 25 SAB isolates were obtained during different collection periods, from which 15 isolates were Gram-positive (Table 1). 
Table 2. Two-way ANOVA of temporal variations in the density of vicinity fouling bacteria (VFB), obtained from aluminum, fiberglass and cupronickel surfaces. These surfaces were immersed in the immediate vicinity of the sponge for $48 \mathrm{~h}$. df: degrees of freedom; SS: sum of squares; MS: mean of squares; $F_{\mathrm{s}}$ : Fisher constant; ns: not significant; ${ }^{*} \mathrm{p} \leq 0.001$

\begin{tabular}{|lrccc|}
\hline & df & SS & MS & $F_{\mathrm{s}}$ \\
\hline Panel & 2 & 0.1419 & 0.0709 & $1.2 \mathrm{~ns}$ \\
Season & 4 & 29.648 & 7.4122 & $126.0^{*}$ \\
Error & 8 & 0.4705 & 0.0588 & \\
Total & 14 & 30.26 & & \\
\hline
\end{tabular}

\section{Vicinity fouling bacteria (VFB)}

The intensity of bacterial colonization on different types of panels (which were immersed in the vicinity of the sponges) also followed a similar trend to that for SAB (Fig. 1). The temporal variation in the density of VFB in the water column was also found to be significant. However, variation in the bacterial density on different types of panels was not significant (Table 2). We obtained 11 isolates in May 1997, 11 isolates in January 1998, 12 isolates in May 1998, 16 isolates in October 1998 and 16 isolates in January 1999 from microfilm developed over different panels, immersed in the vicinity of sponges. VFB were used as test bacteria for antibacterial assays.

\section{Antibacterial activity of sponge extract against SAB}

The antibacterial activity of sponge crude extracts against its associated bacteria (SAB) for respective collection periods showed that, in January 1998 and October 1998, some of the SAB isolates were sensitive, whereas in other collection periods they were resistant to the sponge extract. It was observed that the growth of Bacillus sp. (MSP2.97, MSP2.98 and JSP2.99) was promoted by sponge crude extracts (Table 3 ).

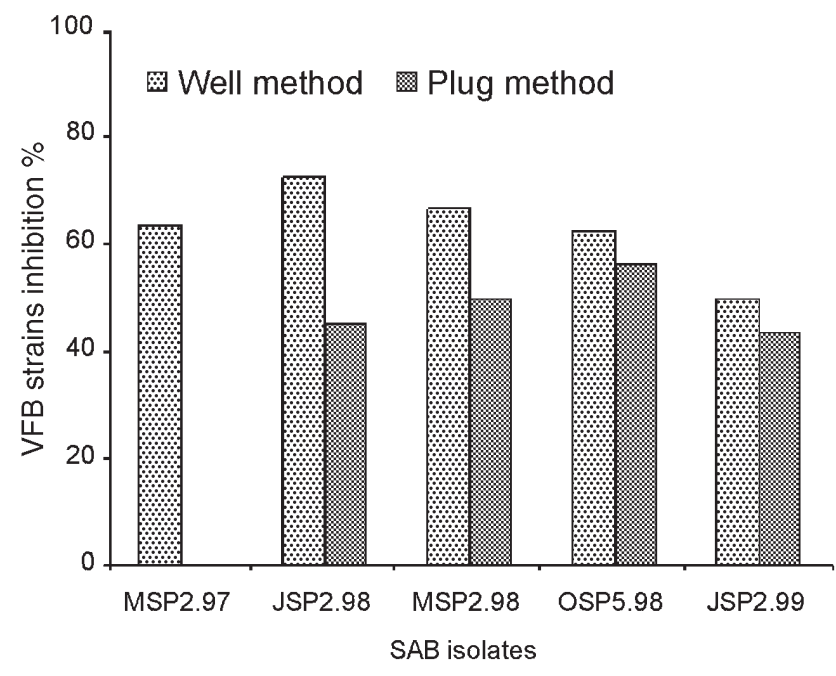

Fig. 2. Percentage inhibition of sponge vicinity fouling bacteria (VFB) by sponge surface-associated bacteria (SAB) in antibacterial assays using the well diffusion and agar plug methods. (See Table 1 for explanation of SAB abbreviations)

\section{Antibacterial activity of SAB against VFB and CFB}

The results in terms of diameter of the inhibition zone are presented in Tables 4 \& 5. In January 98, the antibacterial metabolites were produced by Micrococcus sp. (JSP2.98), whereas in May 97, May 98, October 98 and January 99 they were produced by Bacillus sp. (MSP2.97, MSP2.98, OS5.98 and JSP2.99, respectively). These SAB isolates were also active against 7 CFB isolates without noticeable differences in their activities.

These SAB exhibited activity in both the methods (except MSP2.97, which was inactive in the well diffusion method). However, the percentage of VFB strains inhibited by SAB was always higher in the well diffusion method (Fig. 2). This variation was also observed in the antibacterial assay of SAB against CFB (data not shown). The inhibition zones were also larger in the well diffusion method compared to those in the agar plug method.

Table 3. Antibacterial activity of sponge crude extract collected during different months against sponge surface-associated bacteria of respective collection periods. (Bacterial isolates in bold exhibited antibacterial activity against fouling bacteria). P: promoted (dense) bacterial growth surrounding the disc impregnated with the sponge extract. Diameter of inhibition zone: ,+ 1 to $5 \mathrm{~mm}_{;}-$, no inhibition zone

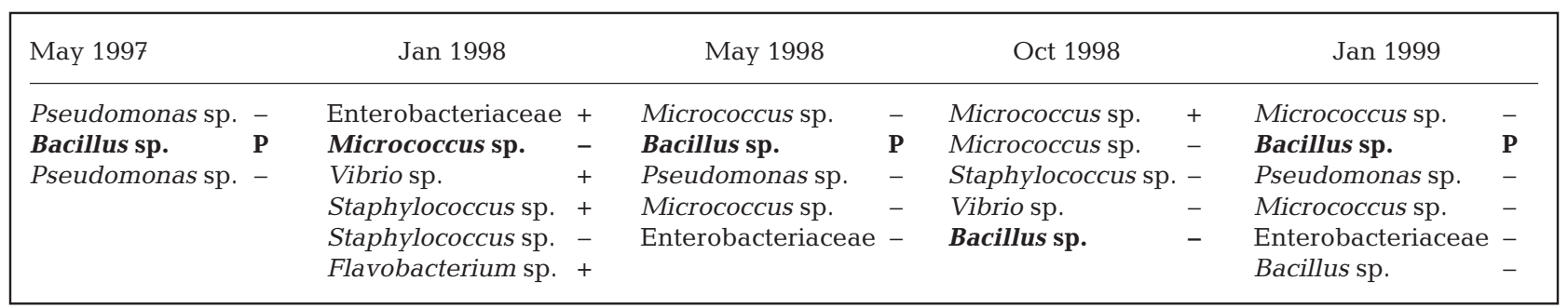


Table 4. Antibacterial activity (diameter of inhibition zone) of sponge surface-associated bacteria (SAB) against sponge vicinity fouling bacteria (VFB) collected during different months using the well diffusion (Well) and agar plug (Plug) methods. A, F, C in isolate codes: bacterial isolates obtained from aluminum, fiberglass and cupronickel panels, respectively; number before period: number of isolates. These fouling bacteria were separated according to their morphological characters. Diameter of inhibition zone:,+ 1 to $5 \mathrm{~mm}_{i}++, 6$ to $10 \mathrm{~mm}_{i}+++,>10 \mathrm{~mm}_{-}-$, no inhibition zone

\begin{tabular}{|c|c|c|c|c|c|c|c|c|c|c|c|c|c|c|}
\hline \multicolumn{3}{|c|}{$\begin{array}{l}\text { Bacillus sp. } \\
\text { (MSP2.97) }\end{array}$} & \multicolumn{3}{|c|}{$\begin{array}{l}\text { Micrococcus sp. } \\
\text { (JSP2.98) }\end{array}$} & \multicolumn{3}{|c|}{$\begin{array}{l}\text { Bacillus sp. } \\
\text { (MSP2.98) }\end{array}$} & \multicolumn{3}{|c|}{$\begin{array}{l}\text { Bacillus sp. } \\
\text { (OSP5.98) }\end{array}$} & \multicolumn{3}{|c|}{$\begin{array}{l}\text { Bacillus sp. } \\
\text { (JSP2.99) }\end{array}$} \\
\hline May 1997 & Well & Plug & Jan 1998 & Well & Plug & May 1998 & Well & Plug & Oct 1998 & Well & Plug & Jan 1999 & Well & Plug \\
\hline MA1.97 & +++ & - & JA1.98 & +++ & ++ & MA1.98 & - & - & OA1.98 & ++ & - & JA1.99 & +++ & ++ \\
\hline MA2.97 & - & - & JA2.98 & ++ & - & MA2.98 & +++ & ++ & OA2.98 & ++ & 6 & JA2.99 & ++ & - \\
\hline MA3.97 & ++ & - & JA3.98 & - & - & MA3.98 & ++ & ++ & OA3.98 & - & - & JA3.99 & - & ++ \\
\hline MF1.97 & ++ & - & JA4.98 & + & ++ & MF1.98 & ++ & ++ & OF1.98 & +++ & 7 & JA4.99 & - & - \\
\hline MF2.97 & ++ & - & JF1.98 & ++ & + & MF2.98 & ++ & - & OF2.98 & ++ & 8 & JA5.99 & ++ & + \\
\hline MF3.97 & - & - & JF2.98 & - & - & MF3.98 & - & - & OF3.98 & - & - & JA6.99 & - & - \\
\hline MC1.97 & - & - & JC1.98 & ++ & - & MF4.98 & ++ & ++ & OF4.98 & - & - & JF1.99 & ++ & ++ \\
\hline MC2.97 & ++ & - & JC2.98 & ++ & - & MF5.98 & ++ & - & OF5.98 & ++ & 6 & JF2.99 & ++ & ++ \\
\hline MC3.97 & - & - & JC3.98 & ++ & ++ & MC1.98 & - & - & OF6.98 & ++ & 5 & JF3.99 & - & - \\
\hline MC4.97 & ++ & - & JC4.98 & - & - & MC2.98 & - & - & OF7.98 & + & 0 & JF4.99 & - & - \\
\hline MC5.97 & ++ & - & JC5.98 & ++ & + & MC3.98 & ++ & ++ & OF8.98 & +++ & 9 & JF5.99 & ++ & - \\
\hline & & & & & & MC4.98 & ++ & + & OC1.98 & - & - & JC1.99 & +++ & ++ \\
\hline & & & & & & & & & OC2.98 & ++ & 6 & JC2.99 & - & - \\
\hline & & & & & & & & & OC3.98 & - & - & JC3.99 & - & - \\
\hline & & & & & & & & & OC4.98 & ++ & 6 & JC4.99 & - & - \\
\hline & & & & & & & & & OC5.98 & - & 4 & JC5.99 & ++ & ++ \\
\hline
\end{tabular}

Table 5. Antibacterial activity (diameter of inhibition zone) of sponge surface-associated bacteria (SAB) against common fouling bacteria (CFB) using the well diffusion (Well) and agar plug (Plug) methods. CFB were obtained from microfilms developed over fiberglass (Enterobacteriaceae, Vibrio sp., Pseudomonas sp.), cupronickel (Moraxella sp., Aeromonas sp.), copper (Micrococcus sp.) and aluminum (Cytophaga sp.) panels exposed for $24 \mathrm{~h}$ at Dona-Paula bay, Goa (west coast of India $15^{\circ} 27.5^{\prime} \mathrm{N}, 73^{\circ} 48^{\prime} \mathrm{E}$ ). G: rapid growth surrounding the plug of SAB against Enterobacteriaceae. Diameter of inhibition zone:,+ 1 to $5 \mathrm{~mm} ;++, 6$ to $10 \mathrm{~mm}_{i}+++,>10 \mathrm{~mm}_{i}-$, no inhibition zone

\begin{tabular}{|c|c|c|c|c|c|c|c|c|c|c|}
\hline \multirow[t]{2}{*}{ CFB isolates } & \multicolumn{2}{|c|}{$\begin{array}{l}\text { Bacillus sp. } \\
\text { (MSP2.97) }\end{array}$} & \multicolumn{2}{|c|}{$\begin{array}{c}\text { Micrococcus sp. } \\
\text { (JSP2.98) }\end{array}$} & \multicolumn{2}{|c|}{$\begin{array}{l}\text { Bacillus sp. } \\
\text { (MSP2.98) }\end{array}$} & \multicolumn{2}{|c|}{$\begin{array}{c}\text { Bacillus sp. } \\
\text { (OSP5.98) }\end{array}$} & \multicolumn{2}{|c|}{$\begin{array}{l}\text { Bacillus sp. } \\
\text { (JSP2.99) }\end{array}$} \\
\hline & Well & Plug & Well & Plug & Well & Plug & Well & Plug & Well & Plug \\
\hline Enterobacteriaceae & - & $\mathrm{G}$ & ++ & $\mathrm{G}$ & + & G & - & G & - & G \\
\hline Vibrio sp. & +++ & - & + & +++ & + & +++ & - & - & ++ & +++ \\
\hline Moraxella sp. & +++ & - & + & +++ & + & +++ & - & - & ++ & +++ \\
\hline Aeromonas sp. & +++ & - & ++ & - & + & - & + & - & + & - \\
\hline Pseudomonas sp. & +++ & - & + & +++ & + & +++ & ++ & - & - & +++ \\
\hline Micrococcus sp. & +++ & - & + & +++ & + & +++ & - & - & - & +++ \\
\hline Cytophaga sp. & - & - & + & +++ & ++ & +++ & ++ & - & ++ & +++ \\
\hline
\end{tabular}

\section{Antibacterial activity of SAB against SAB}

The results of the antibacterial activity of SAB against $\mathrm{SAB}$ of respective collection periods using the well diffusion and agar plug methods were interesting. Some SAB isolates showed antibacterial activity only in the well diffusion method (e.g. MSP1.97 inhibited the growth of MSP3.97), and some only in the agar plug method (e.g. OSP3.98 inhibited the growth of OSP2.98). However, most of the bacteria displayed antibacterial activity in both methods, e.g. MSP2.97 against MSP1.97, JSP2.98 against JSP3.98). All SAB isolates of October 1998 dominated the area surrounding the agar plug against OS4.98 in the agar plug method, whereas OS5.98 of the same collection period showed autotoxicity in both the methods.

\section{Phylogenetic analysis of SAB with antibacterial activity}

16S rDNA sequences of SAB isolates are presented in Table 6. All 3 bacterial isolates (identified by this technique) belonged to the genus Bacillus with 96 to $97 \%$ similarity. 
Table 6. Results of $16 \mathrm{~S}$ rDNA sequence analysis of sponge surface-associated bacteria. Out of 5 SAB isolates with antibacterial activity, JSP2.98 and MSP2.98 could not grow on agar plates after repeated subculture. Hence, identification of the remaining 3 SAB isolates (MSP2.97, OSP5.98 and JSP2.99) was carried out using 16S rRNA gene sequences

\begin{tabular}{|lccrl|}
\hline Isolate & $\begin{array}{c}\text { Bases } \\
\text { sequenced (bp) }\end{array}$ & $\begin{array}{c}\text { Nearest phylogenetic } \\
\text { neighbor }\end{array}$ & $\begin{array}{c}\% \\
\text { similarity }\end{array}$ & Species \\
\hline MSP2.97 & 635 & Bacillus sp. 82344 & 97 & Bacillus sp. \\
OSP5.98 & 720 & Bacillus sp. 83244 & 96 & Bacillus sp. \\
JSP2.99 & 683 & Bacillus sp. 82344 & 96 & Bacillus sp. \\
\hline
\end{tabular}

\section{DISCUSSION}

The possible role of associated bacteria in the epibacterial defense of the host has been documented by several investigators (Holmström et al. 1996, Boyd et al. 1999, Thakur et al. 2003). However, the present study focuses on the role of sponge associated bacteria by considering the influence of temporal changes on their association with the host.

The results showed quantitative variation in bacterial epibiosis on sponge surfaces during different collection periods. In January, the surface of the sponge had fewer bacteria compared to May and October. Similar counts of VFB were obtained. As the study area is influenced by the south-west monsoon, water temperature rises to 30 to $33^{\circ} \mathrm{C}$ in May (prior to the onset of the south-west monsoon) and October (end of the south-west monsoon) and is comparatively cooler in January $\left(26\right.$ to $\left.28^{\circ} \mathrm{C}\right)$. Earlier reports have shown that bacterial density also increases during April-May and September-October in this region (Ramaiah et al. 1996). In view of this, our observation agrees well with the finding that the increase in bacterial density in the water column during warmer months influences the abundance of fouling and/or epibiotic bacterial numbers (Bakus et al. 1990).

Nearly all microorganisms are capable of forming biofilm as this is a universal way of microbial life. It is known that bacteria rapidly colonize living and nonliving surfaces submerged in the sea to form microfilm, a prerequisite of the biofouling process. These colonizing bacteria are fouling bacteria in general, whereas the bacteria colonizing living organisms are known as epibacteria. VFB were isolated from microfilms developed over different surfaces. In this study, toxic (cupronickel) and non-toxic surfaces (aluminum and fiberglass) were immersed in the vicinity of the sponge to obtain VFB and to and isolate a wide range of fouling bacterial strains. We assumed that the bacteria that can settle on toxic and/or non-toxic surfaces would be able to settle on sponge surface. Though this was not always the case, these bacteria represent the fouling bacteria from the sponge vicinity. As VFB isolates varied from season to season, 7 CFB isolates (obtained from other locations) were used in the antibacterial assay to compare the activity of SAB isolates of different collection periods.

The SAB Micrococcus sp. (JSP2.98) displayed antibacterial activity in January 1998. However, in May 1997 (MSP2.97), May 1998 (MSP2.97), October 1998 (OSP5.98) and January 1999 (JSP2.99), antibacterial activity was displayed by bacteria belonging to the genus $B a-$ cillus. These SAB isolates were not only active against fouling bacteria in the vicinity but also against fouling bacteria from other locations. This observation highlights their potential to inhibit the growth of fouling bacteria.

In the present study, the SAB strain belonging to Micrococcus sp. was active against fouling bacteria. Interestingly, bioactive Micrococcus strains have also been isolated from the sponges Xestospongia sp. (New Caledonia), Tedania ignis (Stierle et al. 1988, BultelPonce et al. 1998) and Aplysina aerophoba (Hentschel et al. 2001). We found that the genus Bacillus comprised a phylogenetically and phenotypically heterogeneous group of species, and was common during both warm and cool month collections. Few publications are devoted to the study of Bacillus species isolated from marine environments (Ivanova et al. 1999). This group of bacteria is known to be associated with various marine organisms including sponges and is reported to be a productive source of antibiotic and insecticide metabolites (Fenical \& Jensen 1993). Earlier studies on this genus showed that Bacillus pumilus associated with an Ircinia sp. is able to produce surfactin-like despipeptides, which were earlier thought to be of sponge origin (Kalinovaskaya et al. 1995). In addition, in the present study, a bacterial strain belonging to the genus Bacillus remained associated with the sponge I. fusca and produced antibacterial metabolites, irrespective of season.

The observed association of the genus Bacillus with the sponge Ircinia fusca compares with the earlier reports that some bacterial strains are specific to the host without any temporal and geographical variations (Webster \& Hill 2001). The culturable bacterial strain NW001 has shown such specificity with the marine sponge Rhopaloeides odorabile, collected from the Great Barrier Reef (Webster \& Hill 2001). An experiment carried out with the sponge Aplysina aerophoba, using molecular biological tools, also showed that some bacteria permanently reside in sponge mesohyl, indicating a close interaction between the host and 
associated bacteria (Friedrich et al. 2001). It has also been proven that the maintenance of sponges in aquaria reduces the number of associated bacterial species. However, few bacterial strains still remain encapsulated in special cells, the bacteriocytes (Böhm et al. 2001). In this context, the observed close association of a bacterial strain of the genus Bacillus with the marine sponge I. fusca needs to be explored using cell biological (possibly by developing sponge primmorph culture) and molecular biological techniques.

It is interesting to note that the $60 \%$ of the SAB obtained in this study were Gram-positive, and only Gram-positive SAB isolates were found to exhibit antibacterial activity. Gram-positive bacteria are known to generate spores under adverse conditions; they also have a wide range of physiological adaptations, which might help to ensure their survival on the sponge surface. It has also been reported that the spore formation is co-regulated with antibiotic production (Marahiel et al. 1993).

The results of the antibacterial assay of sponge extract against $\mathrm{SAB}$ of the respective collection period were very interesting. The growth of Bacillus sp., which displayed antibacterial activity, was promoted by sponge extract; this indicates that sponge support the growth of selective bacterial strains on its surface, which probably help the host by deterring other microbes. It remains possible that bacteria inhabiting the sponge surface may compete with their neighbors for space and nutrients by producing some active metabolites. These metabolites could possibly deter other bacteria from the surrounding environment from colonizing the sponge surface.

In order to study the interaction among $\mathrm{SAB}$, they were evaluated for antibacterial activity against each other, using the well diffusion and agar plug methods. Some of the SAB selectively inhibited the growth of their neighbors, which indicates that the antibacterial metabolites can confer a selective advantage to the producer (for competition with other bacteria) populating the host surface. In the agar plug assay, the SAB of October 1998 always grew very fast and dominated the area surrounding the plug against their neighbor, Vibrio sp. (OSP4.98). This observation suggests that the production of antibacterial metabolites is not the only way to compete with other bacteria, but that some bacteria can also compete with their neighbors for space and nutrients by maintaining their rapid growth. The Bacillus sp. (OSP5.98) showed auto-inhibition (data not shown), which is a widely occurring phenomenon in marine bacteria and has been reported in many studies (Holmström \& Kjelleberg 1999). Researchers opined that the production of auto-toxic metabolites in bacteria is important to inhibit their further growth in dense culture in order to acquire adequate nutrients for their better survival. In addition, auto-inhibitory compounds produced by Gram-positive and -negative bacteria may prevent the predominance of specific bacterial strains and maintain bacterial diversity in the habitat (Holmström et al. 2002). These results suggest that the sponge associated bacteria modulate the growth of their own cells as well as their neighbors by producing active metabolites. This bacterial mechanism could indirectly help the sponge to control bacterial epibiosis on its surfaces.

The presence of antibacterial activity in SAB was detected using 2 different methods: the commonly used well diffusion method and the agar plug method, which was used by Hentschel et al. (2001). In the present study, both methods were used simultaneously. The percentage of fouling bacterial isolates inhibited by $\mathrm{SAB}$ in the well diffusion method was always higher compared to the agar plug method. In the well diffusion method, the concentration of bacterial metabolites tested may not be ecologically realistic. Hence, the results of such an assay can be presumed to have no ecological relevance. In the agar plug assay, bacterial interaction was evaluated by directly testing bacteria

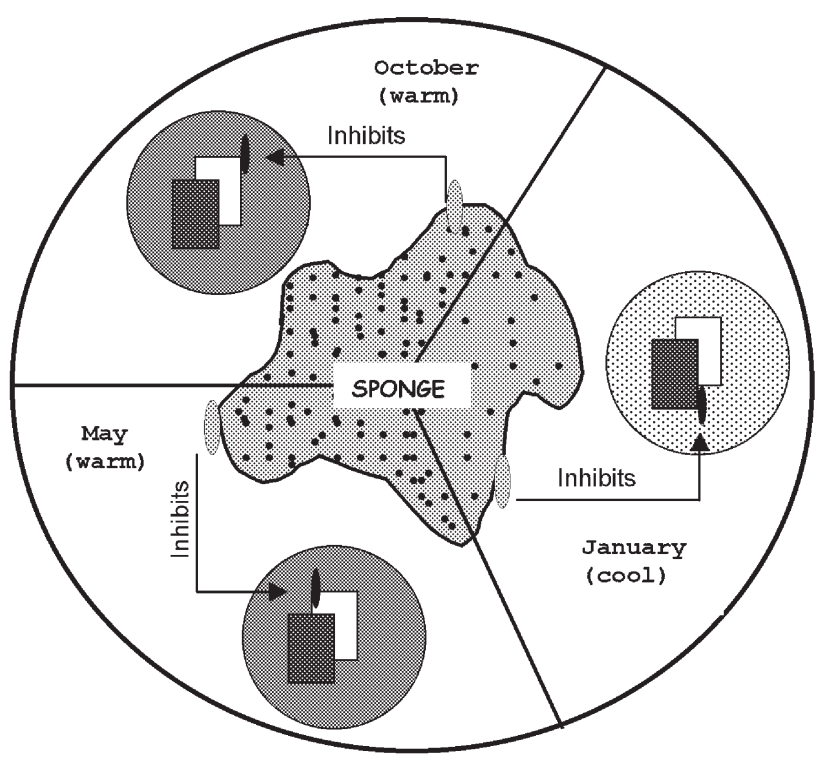

Fig. 3. Schematic diagram showing the influence of temporal variations on the density of sponge surface-associated (SAB) and vicinity fouling bacteria (VFB) and the possible role of associated bacteria in sponge epibacterial defense. In warm months (May and October) SAB and VFB density seems to be higher than when it is cool (January). Bacillus sp. with antibacterial activity against fouling bacteria was found to be associated with the sponge in every collection period. 9: sponge-associated bacterium Bacillus sp.; | : fouling bacteria from different surfaces immersed in the vicinity of the sponge; increased bacterial density in the sponge vicinity;

1: decreased bacterial density in the sponge vicinity; $\square$ : sponge associated bacterium Bacillus sp.; $\quad$ : VFB 
against bacteria, instead of extracting their metabolites, a method which seems to be ecologically relevant. The larger inhibition zones in the well diffusion assay compared to the agar plug assay can be attributed to the higher concentration and the way bacterial metabolites were exposed to the test bacteria. All these observations highlight the advantages of the agar plug assay in ecological studies.

In summary, this investigation demonstrated that epibacterial density on the sponge surface is influenced by temporal changes in the environment (Fig. 3). However, some bacterial strains may have a close association with the host sponge. Sponge seems to have a selective control on bacterial epibiosis and it promotes the growth of specific bacteria which may assist their host to control epibiosis. This study supports the possible role of sponge associated bacteria in host epibacterial defense and warrants further research to explore sponge-bacteria association by using cell biological and molecular biological approaches.

Acknowledgements. We are grateful to Dr. E. Desa, former Director of the National Institute of Oceanography, Goa, India, for his support and encouragement. We gratefully acknowledge the support of Dr. N. B. Bhosle, Marine Corrosion and Materials Research Division (MCMRD), and Dr. A. B. Wagh, former Deputy Director and Head of the MCMRD, for carrying out this investigation. We are grateful to Dr. Ute Hentschel, Universität Würzburg, Germany, for her help in phylogenetic analysis of bacteria and also for the careful revision of this paper. Thanks are also due to Mr. K. Venkat, Dr. D. Desai, Mr. Y Vishwakiran, Dr. J. Patil, Mr. S. Naik and Mr. N. Prabhu for their help in the collection of sponge specimens. We thankful Dr. P. A. Thomas, Vizhinjam Research Centre of Central Marine Fisheries Research Institute, Thiruvananthapuram, India, for the identification of sponge species. N.L.T. thanks the Council of Scientific and Industrial Research (India) for the award of 'Senior Research Fellowship'. This work was supported by Indo-US PL-480 project (ONR Grant No: 000114-J-90-1152) and is NIO contribution number 3947.

\section{LITERATURE CITED}

Althoff K, Schütt C, Steffen R, Batel R, Müller WEG (1998) Evidence for a symbiosis between bacteria of the genus Rhodobacter and the marine sponge Halichondria panicea: harbor also for putatively toxic bacteria. Mar Biol 130:529-536

Amade P, Charroin C, Baby C, Vacelet J (1987) Antimicrobial activities of marine sponges from the Mediterranean Sea. Mar Biol 94:271-275

Bakus GJ, Shulte B, Jhu S, Wright M, Green G, Gomez P (1990) Antibiosis and antifouling in marine sponges: laboratory versus field studies. In: Ruetzler K (ed) New perspectives in sponge biology. Proc 3rd Int Sponge Conf, 17-23 November 1985. Woods Hole Oceanographic Institute, Woods Hole, MA, p 102-108

Becerro MA, Lopez NI, Turon X, Uriz MJ (1994) Antimicrobial activity and surface bacterial film in marine sponges. J Exp Mar Biol Ecol 179:195-205

Böhm M, Hentschel U, Friedrich AB, Fieseler L, Steffen R,
Gamulin V, Müller, IM, Müller WEG (2001) Molecular response of the sponge Suberites domuncula to bacterial infection. Mar Biol 139:1037-1045

Boyd KG, Adams DR, Burgess JD (1999) Antibacterial and repellent activities of marine bacteria associated with algal surfaces. Biofouling 14:227-236

Buchanan RE, Gibbons NE (1984) Bergeys manual of determinative bacteriology, 8th edn. Williams \& Wilkins, Baltimore

Bultel-Ponce V, Debitus C, Berge JP, Cerceau C, Guyot M (1998) Metabolites from the sponge-associated bacterium Micrococcus luteus. J Mar Biotechnol 6:233-236

Elyakov GB, Kuznetsova TA, Mikhailov VV (1996) From chemistry of marine natural products to marine technologies: research at the pacific institute of bioorganic chemistry. Mar Technol Soc J 30:21-28

Faulkner DJ (1997) Marine natural products. Nat Prod Rep 14: 259-302

Fenical W, Jensen PR (1993) Marine microorganisms: a new biomedical resource, Chap 12. In: Attaway DH, Zabrosky OR (eds) Marine biotechnology: pharmaceutical and bioactive natural products. Plenum Press, New York, p 419-457

Friedrich AB, Merkert H, Fendert T, Hacker J, Proksch P, Hentschel U (1999) Microbial diversity in the marine sponge Aplysinia cavernicola (formerly Verongia cavernicola) analyzed by fluorescence in situ hybridization (FISH). Mar Biol 134:461-470

Friedrich AB, Fischer I, Proksch P, Hacker J, Hentschel U (2001) Temporal variation of the microbial community associated with the Mediterranean sponge Aplysina aerophoba. FEMS Microbiol Ecol 38:105-113

Harder T, Lau SCK, Dobretsov S, Fang TK, Qian PY (2003) A distinctive epibiotic bacterial community on the soft coral Dendronephthya sp. and antibacterial activity of coral tissue extracts suggest a chemical mechanism against bacterial epibiosis. FEMS Microbiol Ecol 43:337-347

Hentschel U, Schmid M, Wagner M, Fieseler L, Gernert C, Hacker J (2001) Isolation and phylogenatic analysis of bacteria with antimicrobial activities from the Mediterranean sponges Aplysina aerophoba and Aplysina cavernicola. FEMS Microbiol Ecol 35:305-312

Holmström C, Kjelleberg S (1999) Marine Pseudoalteromonas species are associated with higher organisms and produce biologically active extracellular agents. FEMS Microbiol Ecol 30:285-293

Holmström C, James S, Egan S, Kjelleberg S (1996) Inhibition of common fouling organisms by pigmented marine bacterial isolates. Biofouling 10:251-259

Holmström C, Egan S, Franks A, McCloy, S, Kjelleberg S (2002) Antifouling activities expressed by marine surface associated Pseudoalteromonas species. FEMS Microbiol Ecol 41:47-58

Ivanova EP, Vysotskii MV, Svetashev VI, Nedashkovskaya OI and 6 others (1999) Characterization of Bacillus strains of marine origin. Int Microbiol 2:267-271

Kalinovskaya N, Kuznetsova T, Rashkes Ya, Mil'grom Yu and 7 others (1995) Surfactin like structures of five cyclic depsipeptides from the marine isolate of Bacillus pumilus. Russ Chem Bull (English translation) 44:951-955

Kelman D, Kashman Y, Rosenberg E, Ilan M, Ifrach I, Loya Y (2001) Antimicrobial activity of the reef sponge Amphimedon viridis from the Red Sea: evidence for selective toxicity. Aquat Microb Ecol 24:9-16

Marahiel MA, Nakano MM, Zuber P (1993) Regulation of peptide antibiotic production in Bacillus. Mol Microbiol 7: 631-636

McCaffrey EJ, Endean R (1985) Antimicrobial activity of tropical and subtropical sponges. Mar Biol 89:1-8 
Newbold RW, Jensen PR, Fenical W, Pawlik JR (1999) Antimicrobial activity of Caribbean sponge extracts. Aquat Microb Ecol 19:279-284

Patil JS, Anil AC (2000) Epibiotic community of the horseshoe crab Tachypleus gigas. Mar Biol 136:699-713

Ramaiah N, Raghukumar S, Gaus M (1996) Bacterial abundance and production in the central and eastern Arabian sea. Curr Sci (Special Section: JGOFS, India) 71:878-82

Santavy DL, Willenz P, Colwell RR (1990) Phenotypic study of bacteria associated with the Caribbean sclerosponge Ceratoporella nicholsoni. Appl Environ Microbiol 56: 1750-1762

Schröder HC, Brümmer F, Fattorusso E, Aiello A, Menna M, de Rosa S, Batel R, Müller WEG (2003) Sustainable production of bioactive compounds from sponges: primmorphs as bioreactors. In: Müller WEG (ed) Marine molecular biotechnology. Springer-Verlag, Berlin, p 163-197

Slattery M, McClintock JB, Heine JN (1995) Chemical defenses in Antarctic soft corals: evidence for antifouling compounds. J Exp Mar Biol Ecol 190:61-77

Sokal PR, Rohlf FJ (1981) Biometry, 2nd edn. WH Freeman, San Francisco

Steinberg PD, Schneider R, Kjelleberg S (1997) Chemical defenses of seaweeds against microbial colonization. Biodegradation 8:211-220

Stierle AC, Cardellina JH II, Singleton FL (1988) A marine Micrococcus produces metabolites ascribed to the sponge Tedania ignis. Experentia 44:1021

Thakur NL (2001) Studies on some bioactivity aspects of selected marine organisms. PhD thesis, Goa University

Thakur NL, Anil AC (2000) Antibacterial activity of the sponge Ircinia ramosa: importance of its surface associated bacteria. J Chem Ecol 26:57-71

Thacker RW, Starnes S (2003) Host specificity of the symbiotic

Editorial responsibility: John Dolan, Villefranche-sur-Mer, France cyanobacterium Oscillatoria spongeliae in marine sponges, Dysidea spp. Mar Biol 142:643-648

Thakur NL, Hentschel U, Krasko A, Pabel CT, Anil AC, Müller WEG (2003) Antibacterial activity of the sponge Suberites domuncula and its primorphs: potential basis for epibacterial chemical defense. Aquat Microb Ecol 31: 77-83

Vacelet J (1975) Etude en microscopie éléctronique de l'association entre bactéries et spongiaires du genre Verongia (Dictyoceretida). J Microsc Biol Cell 23: 271-288

Vacelet J, Donadey C (1977) Electron microscope study of the association between some sponge and bacteria. J Exp Mar Biol Ecol 30:301-314

Wahl M (1989) Marine epibiosis. 1. Fouling and antifouling: some basic aspects. Mar Ecol Prog Ser 58:175-189

Wahl M, Jensen PR, Fenical W (1994) Chemical control of bacterial epibiosis on ascidians. Mar Ecol Prog Ser 110:45-57

Webster NS, Hill RT (2001) The culturable microbial community of the Great Barrier Reef sponge Rhopaloeides odorabile dominated by an $\alpha$-Proteobacterium. Mar Biol 138: 843-851

Webster NS, Wilson KJ, Blackall LL, Hill RT (2001) Phylogenetic diversity of bacteria associated with the marine sponge Rhopaloeides odorabile. Appl Environ Microbiol 67:434-444

Wilkinson CR (1978a) Microbial association in sponges. I. Ecology, physiology and microbial populations of coral reef sponges. Mar Biol 49:161-167

Wilkinson CR (1978b) Microbial association in sponges. II. Numerical analysis of sponge and water bacterial populations. Mar Biol 49:169-176

Wilkinson CR (1978c) Microbial association in sponges. III. Ultrastructure of the in situ associations in coral reef sponges. Mar Biol 49:177-185

Submitted: September 18, 2003; Accepted: September 1, 2004 Proofs received from author(s): November 30, 2004 